\title{
Kadınlarda Menstruasyon Döngüsüne Bağlı Olarak Beslenme Durumu ve Antropometrik Ölçümlerdeki Değişikliklerin Araştırılması: Kesitsel Bir Çalışma
}

\section{Investigation of Changes in Nutritional Status and Anthropometric Measurements Depending on the Menstrual Cycle in Women: A Cross-Sectional Study}

\author{
${ }^{1}$ Hilal HIZLI GÜLDEMIR, ${ }^{2}$ Şule KIYAK, ${ }^{2}$ Ahsen Fulya ERTOSUN, ${ }^{2}$ İlkay ERYILMAZ, \\ ${ }^{2}$ Parikhonum GASANOVA \\ ${ }^{1}$ Kutahya Health Sciences University, Faculty of Health Sciences, Department of Nutrition and Dietetics, Kutahya, Turkey
${ }^{2}$ Istanbul Medipol University, Faculty of Health Sciences, Department of Nutrition and Dietetics, Istanbul, Turkey
}

\author{
Hilal Hızlı Güldemir: https://orcid.org/0000-0002-3951-5023 \\ Şule Kiyak: https://orcid.org/0000-0001-9142-3145 \\ Ahsen Fulya Ertosun: https://orcid.org/0000-0002-7061-4628 \\ İlkay Eryllmaz: https://orcid.org/0000-0002-5108-4043 \\ Parikhonum Gasanova: https://orcid.org/0000-0003-1356-772X
}

\section{ÖZ}

Amaç: Bu çalışmanın temel amacı, 18-25 yaşları arasındaki 80 Türk kadının, menstrüel siklusları boyunca beslenme durumlarını ve vücut kompozisyonlarındaki değişimleri araştırmaktır.

Materyal ve Metot: Demografik bilgiler ve besin alımı verileri önceden yapılandırılmış bir anketle toplanmıştır. Kadınların vücut ölçümleri BIA yöntemiyle, menstruasyon sırasında ve sonrasındaki 4 günde olmak üzere $2 \mathrm{kez}$ alınmıştır. Besin tüketim kayıtları analiz edilerek enerji ve besin öğesi alımları değerlendirilmiştir. İstatistiksel analizlerde SPSS 18.0 programı kullanılmıştır.

Bulgular: Katılımcıların yaş ortalaması $21.6 \pm 1.68$ yıldır. Menstruasyon döngüsü sırasındaki ve sonrasındaki ölçümleri karşılaştırıldığında, vücut ağırlıkları, bel çevresi ve göğüs çevresi artışları sırasıyla $0.32 \mathrm{~kg}, 0.90 \mathrm{~cm}$ ve $0.57 \mathrm{~cm}$ bulunmuştur. $\mathrm{Bu}$ değişiklikler istatistiksel olarak anlamlıdır $(\mathrm{p}<0.05)$. Enerji, karbonhidrat ve protein alımları iki döngü arasında yükselirken, menstrüel fazda yağ alımı daha düşüktür, ancak istatistiksel olarak anlamlılık görülmemiştir ( $\mathrm{p}>0.05)$.

Sonuç: Her ne kadar çeşitli çalışmalar menstruasyon dönemine odaklanmış olsa da, çalışmamızın yeniliği, özellikle bu dönemde besin öğesi alımını da değerlendirmesidir. Menstruasyon döngüsüne bağlı olarak kadınların enerji ve besin öğesi alımlarında farklılık olmadığı görülmüştür.

Anahtar Kelimeler: Beslenme, besin öğesi, menstruasyon, vücut kompozisyonu

\section{ABSTRACT}

Objective: The primary aim of this study is to investigate the nutritional status and body composition changes of 80 Turkish women within the age of 18-25 years during their menstrual cycles.

Materials and Methods: Demographical and food intake behavior data were collected by a public survey. Body measurements of women were obtained 2 times; during and after the next four days of menstruation by BIA. Food intake records were taken to analzye energy and nutrient intakes. SPSS 18.0 program was used for statistical analyses.

Results: The average age of participants was found $21.6 \pm 1.68$ years. Comparing women in during and after menstrual cycle, their body weight, waist circumference and chest circumference increments were found $0.32 \mathrm{~kg}$, $0.90 \mathrm{~cm}$ and $0.57 \mathrm{~cm}$ respectively. These changes were statistically significant $(p<0.05)$. Energy, carbohydrate and protein intakes elevated between two cycles, whereas fat intake was lower in menstrual phase, however no statistical significance was observed ( $\mathrm{p}>0.05$ ).

Conclusions: Although various previous studies focused on the menstruation period, the novelty of our study lies within multiple parameters that we correleated, especially nutrient intake. There was no difference in energy and nutrient intake of women depending on the menstruation periods.

Keywords: Body composition, nutrients, menstruation, nutrition

\section{Sorumlu Yazar / Corresponding Author:}

Hilal Hızlı Güldemir

Kutahya Health Sciences University, Faculty of Health Sciences,

Department of Nutrition and Dietetics, Kutahya, Turkey

Tel: 05052643270

E-mail: hilal.hizliguldemir@ksbu.edu.tr
Yayın Bilgisi / Article Info:

Gönderi Tarihi/ Received: 01/08/2019

Kabul Tarihi/ Accepted: 12/06/2020

Online Yayın Tarihi/ Published: 30/09/2020

*Atıf / Cited: Hızlı Güldemiz H et al. Assessment of the Nutritional Status and Body Composition in Menstrual Cycles. Online Türk Săglık Bilimleri Dergisi 2020;5(3):406-414. doi: 10.26453/otjhs.599949

*The manuscript has been presented in a congress as a poster, Union of Thrace Universities 2nd International Health Sciences Congress Tekirdağ, 15-17 November 2018. 


\section{INTRODUCTION}

The menstrual cycle is characterized by repetitive hormonal changes and menstrual bleeding for reproduction from menarche to menopause, which affects the whole organism, especially the genital system. Duration of a cycle is mostly $28 \pm 7$ days. It usually starts at ages 10-12 and ends at 45-50. Menstrual cycle is profoundly affected by wide range of factors including age, physical environment, emotional state, malnutrition, excessive weight loss, metabolic disorders and fatigue. ${ }^{1,2}$ Multiple physiological and psychological alterations such as depression, mood changes, tension, irritability, fatigue, headache, breast tenderness, increased appetite and edema may occur during the premenstrual period. Women spend their majority of lives experiencing these problems with physical, behavioral and emotional changes since menstruation cycles last for years. There are some suggestions to overcome this period as much as possible, such as giving information about the physical changes in menstrual period and hygiene habits to protect reproductive health. ${ }^{3-5}$ Menstrual problems are generally perceived as minor health concerns and thus excluded from the public health agenda particularly in developing countries, where women are facing life threatening conditions. The effects of dietary habits on menstrual cycle are observed in both malnutrition and excessive nutrition states. Studies demonstrated that in terms of menstrual cycle, irregularities and ovulation, energy balance of the body is more crucial than the body weight. Previous studies exhibited that menstrual cycles are disrupted significantly in cases with nutritional problems. ${ }^{6,7}$ For instance, in pubertal girls increased iron losses due to menstruation elevate the risk of iron depletion. In this context, Hallberg et al. reported high prevalence of iron depletion in pubertal girls, which was found to differentiate based on their menstrual status, dietary habits, use of supplements and oral contraceptives. ${ }^{8,9}$ Therefore, nutrition professionals demand information about the nature of menstrual periods and changes in body compositions, along with information including diet, food intake and change in eating habits to meet these requirements. Hence, the purpose of this study is to identify any potential correlation between nutritional status and body compositions, experienced in menstrual cycles of Turkish university students.

\section{MATERIALS AND METHODS}

In this retrospective cross-sectional study, this research was conducted on May 2018 - February 2019 with 18-25 years old women. The participants consisted of 80 Turkish women, who were Istanbul Medipol University students and consented to enroll to the study. The participation criterias included regular menstruation cycles with no pregnancy, lactation status, gynecological problems, psychiatric diseases and history of drug usage. This study was performed within the quidelines of the Helsinki Declaration. This study was approved by Istanbul Medipol University Ethics Committee (Date: 01/11/2019, decision no: 10840098-604.01.01-E.59753). All participants were informed about the purpose of this research and were ensured that their information would remain confidential.

Individuals who were previously informed about the research were included in the study. Research data were collected by means of measurement tools and questionnaires developed by researchers. The majority of the survey contained structured questions. The questionnaire was administered through face-toface interviews with individuals, which consists of 25 questions in four sections and performed in the first day and within 4 days after the menstruation. These four sections consist of demographic information, anthropometric measurements, nutritional habits and changes in food desires, food consumption records. The questionnaires were provided to female students at the university break time from 12 to 1 $\mathrm{pm}$. The questionnaires and anthropometric measurements were distributed in Department of Nutrition and Dietetics practice room of Istanbul Medipol University. The questionnaire took an average of 10 minutes to answer all the questions, which were retrospective to the last six months. In the nutritional habits section of the questionnaire, there are questions about the changes in the food preferences, desire to consume foods which is not usually consumed, and appetite changes of women in the premenstrual period, covering the one week period before menstruation.

Body weight and height measurements were obtained by the researcher and body mass indexes (BMI) were calculated as $\mathrm{kg} / \mathrm{m}^{2}$. Body weights were measured with thin clothes, shoes and socks. The heights were measured by obtaining the posture with adjacent feet and on the head of the Frankfurt plane. The waist, hip and chest circumferences were measured by the researcher using a non-stretched tape measure. Waist circumference measurements were 
governed at the point where it is the leanest between lower rib and cristainee, and the measurement was performed from the midpoint. Hip circumference measurements were performed at the greatest point. The chest circumference was measured from the nipple line while in the middle of breathing.

Food consumption records of the participants were taken 24 hours retrospectively by the researchers on the preceding day. The dietary record used by researchers was conducted based on widely accepted and applied rules - using a pre-structured format, with additional questions including the name of the meal, time and location of consumption, meal ingredients, the weight (weighed using a kitchen scale) or the size of the serving (estimated using standard household measures). After determining the amount of food intake; dietary energy and nutrient intakes were evaluated using Nutrition Information Systems Package Program 7.2 (BEBIS 7.2), which is commonly used in Turkey.

In this study, 80 young women had included. The study reached 0,80 power with a medium $(\% 30)$ effect size and $\alpha=0,05$. The results were presented through descriptive statistics, as arithmetic mean and standard deviation (SD) for interval and ratio scale, and percentages for categoric variables. The suitability of the variables to normal distribution was analyzed by analytical and graphical methods. Dependent samples $t$ test was used for normal distribution and Wilcoxon Sign Rank test was used for unsuitable ones. The $\mathrm{p} \leq 0.05$ was indicated as significant. The data were evaluated with IBM SPSS (Statistical Package for Social Sciences) 22.0 package program.

\section{RESULTS}

Demographical data of the individuals were given in Table 1 . The mean age of the subjects was $21.61 \pm$ 1.68 years. According to the data; $72.5 \%$ of individuals had secondary education, $11.3 \%$ had associate degree and $16.3 \%$ had undergraduate; $92.5 \%$ were single and $7.5 \%$ were married; $55 \%$ stayed at dormitory and $45 \%$ lived at home.

Evaluation of the anthropometric measurements before and after menstruation was demonstrated in Table 2. According to the results of bilateral comparison, it was determined that there was a significant difference between body weight, BMI, waist circumference, hip circumference and chest circumference during and after menstruation $(\mathrm{p}<0.05)$.

Table 3 presents the evaluation of energy, macro nutrients, vitamin and mineral intake of individuals during and after menstrual cycle. The mean energy intake of the individuals in the study was $1556.10 \pm$ $347.75 \mathrm{kcal} /$ day and the mean energy intake after the menstruation period was $1575.63 \pm 429.82 \mathrm{kcal} /$ day. There was no statistically significant difference in terms of energy levels and nutrient intake and no significance was observed between menstrual periods ( $\mathrm{p}>0.05)$.

The effect of menstruation on the appetite of individuals was manifested in Table 4. It was determined that $62.5 \%$ of the participants had increased and $3.8 \%$ had decreased appetite during the premenstrual period, whereas $33.8 \%$ of them did not experience appetite change. While $47.5 \%$ of the individuals who participated in the study declared that in the premenstrual period they crave for foods, which were not usually consumed, $52.5 \%$ stated that they did not have such tendencies.

\section{DISCUSSION AND CONCLUSION}

In this study, we aimed to determine the relationship between nutritional status and body compositions on menstrual periods. A total of 80 Turkish women were included in the study. The mean age of the subjects was $21.61 \pm 1.68$ years. Most participants were secondary school graduates, who were living in dormitories.

The body weight, BMI, waist, hip and chest circumference were found to be significantly different during and after menstrual period. Our findings on body weight differences during menstruation periods are in parallel with the literature. In a study conducted by 18-36 year-old women, Dibrezzo et al. ${ }^{3}$ demonstrated that the highest body weight value was observed on the first day of the menstruation and the lowest on the luteal phase. Meanwhile, Çakmakçı et al. ${ }^{4}$ manifested that the highest body weight was measured on the $2^{\text {nd }}$ day of menstrual period and the lowest body on the $14^{\text {th }}$ day. In another study, Türkoğlu ${ }^{10}$ reported that the body weight, body composition and physical activity levels of the individuals were not statistically significant throughout the menstrual cycle. However, Esin et al. ${ }^{11}$ observed a significant increase in body weight and BMI values of women before menstruation and an increase of $0.4 \pm 0.69 \mathrm{~kg}$ in body weight $(\mathrm{p}<0.05)$. The physical changes seen in this period included swelling in the abdomen and chest, edema in the ankles and legs and the increase in body weight due to the accumulation of fluid.

Up to date, no study has focused on a wide correlation between menstrual cycle and food intake. The 
general consensus included an increase in energy intake during the premenstrual period compared to the postmenstrual period, although reports on macronutrients were less consistent. In our study, we found that fat intake increased during menstruation period; yet energy, protein and carbohydrate intakes decreased. The difference between periods was not statistically significant $(p>0.05)$. Type of nutrient intake altered greatly between periods due to consumption of palatable foods such as chocolate and sweets during the menstruation period. Similar to our study, Çukurovalı et al. ${ }^{12}$ also showed that during the menstruation period protein and carbohydrate intake decreased, in constrast to fat consumption, which was found highly increased. Unlike our study, an increase in energy intake was observed. Yet, it was stated that the carbohydrate amounts taken on the basis of menstruation periods did not differ statistically. Another study concentrated on the consumption of foods and premenstrual sydrome (PMS) showed that food intake increased in the premenstrual period while the consumption of foods containing complex carbohydrates decreased. ${ }^{13}$ Food intake related to menstruation was evaluated on a study, in which food consumptions of the participants in three different periods were examined and the amount of carbohydrate, protein and fat taken in premenstrual period was found to be significantly higher than the menstrual period. ${ }^{14}$ However, in a previous research comparing food intake, nutrients, and serum levels of estrogen, progesterone and leptin during the phases of the menstrual cycle in 39 Thai women aged between 20 and 40 years, the authors reported that, although consuming more total calories $(160 \mathrm{kcal} /$ day, $\mathrm{p}<0.05)$ and more grams of proteins $(6-8 \mathrm{~g} /$ day, $\mathrm{p}<0.01)$ during the luteal phase compared to the follicular phase, no correlations were observed between the serum levels of sex hormones, serum leptin levels, food intake, or body weight. $^{15}$

Nutrition, stress, and emotion are among environmental factors that can interfere with the menstrual cycle. ${ }^{16,17}$ In a study conducted by Sezer et al. ${ }^{18}$, the frequency of appetite changes was found as $70.2 \%$. Çukurovalı et al. ${ }^{12}$ determined that $62.0 \%$ of individuals had elevated appetite during premenstrual period and $52.0 \%$ of the individuals stated that in PMS, they had a tendency towards foods, that were not consumed regularly. In a study of Bronzi de Souza et al. ${ }^{19}$, the desire for foods rich in sugar, salt, and fat, such as chocolate, pastries, snacks and desserts were found much higher $(\mathrm{p}<0.05)$ during PMS, although it did not reflect neither a higher energy intake nor an alteration in the distribution of macronutrients. In our study, $66.2 \%$ of individuals experienced appetite changes and $42.5 \%$ craved for foods they did not consume usually in the premenstruation period, similar to other studies.

Menstrual cycles may be influenced by the individual's nutritional status, genetic structure, physiological and psychological state. Previous data from the literature pointed out the existence of changes in body composition during menstrual cycle and few studies addressed energy and nutrients intake and changes in eating behavior of Turkish women. One of the most important results of our study is the significant changes in anthropometric measurements. It was determined that there was a significant increase in body weight and waist, hip and chest circumferences around the beginning of the menstrual period. Moreover, most of the participants stated that their appetite increased during the premenstrual period and nearly half of them desired some foods that they did not consume much before. Despite the changes in anthropometric measurements and appetite; total calorie intake, macro and micronutrients did not fluctuate in the first day and after the menstrual cycle. It should be explained to women that the anthropometric changes that occur during this period and the increase in appetite are normal and may differ in each individual. Individual nutritional recommendations can be supported during this period to reduce nutritional problems. Providing healthy and balanced recipes especially for food cravings can help women cope with this situation. Nevertheless, it is cruicial for health professionals, especially nutritionists and gynecologists, to know the possible oscillations that might occur in the premenstrual period and to consider them for research on food intake and appetite, as well as to provide differentiated care at this stage.

Ethics Committee Approval: Our study approved by the Istanbul Medipol University Ethics Committee (Date:01/11/2019, decision no: 10840098-604.01.01 -E.59753).

Conflict of Interest: No conflict of interest was declared by the authors.

Author Contributions: Concept-HHG; SupervisionHHG; Materials-ŞK, AFE; Data Collection and/or Processing-AFE, IE, PG; Analysis and/ or Interpretation-HHG, IE; Writing-HHG.

Peer-review: Externally peer-reviewed. 


\section{REFERENCES}

1. Mihm M, Gangooly S, Muttukrishna S. The normal menstrual cycle in women. Anim Reprod Sci. 2011;124(3-4):229-236. doi: 10.1016/ j.anireprosci.2010.08.030

2. Hedayat KM, Lapraz JC, Schuff B. Menstruation, Normal Cycle. In: The Theory of Endobiogeny Volume 4: Bedside Handbook. 1st ed. London Wall, London: Academic Press; 2019: 978-0-12-816965-0.

3. Goldstuck ND. Modern menstruation: Is it abnormal or unhealthy? Medical Hypotheses. 2020;144:109955.

4. Çakmakçı E, Sanioğlu A, Patlar S, Çakmakçı O, Çınar V. The effect of menstruation on anaerobic power. Spormetre. 2005;3(4):145-149.

5. Biggs WS, Demuth RH. Premenstrual syndrome and premenstrual dysphoric disorder. Am Fam Physician. 2011;84(8):918-924.

6. Jamieson MA. Disorders of menstruation in adolescent girls. Ped Clin North America 2015; 62 (4): 943-961.

7. Selçuk KT, Avcı D, Yılmaz F. Premenstrual syndrome prevalence and affecting factors in nursing students. J Psy Nurs. 2014;5(2):98-103.

8. Moreno LA, Gottrand F, Huybrechts I, et al. Nutrition and Lifestyle in European Adolescents: The HELENA (Healthy Lifestyle in Europe by Nutrition in Adolescence) Study. Advances in Nutrition. 2014;5(5):615-623. doi: 10.3945/ an.113.005678

9. Hanson MA, Bardsley A, De-Regil LM. The International Federation of Gynecology and $\mathrm{Ob}$ stetrics (FIGO) recommendations on adolescent, preconception, and maternal nutrition: "Think Nutrition First". Int J Gynecol Obstet. 2015;131 (4):213-253.

10. Türkoğlu İ, Pekcan G. Determination of individual differences in resting metabolic rate, body composition and nutrient intake during the menstrual cycle. J Nutr Diet. 2013;41(3):212-220.

11. Esin K, Köksal E, Hızlı H, Garipagaoglu M. Effects of Menstrual Cycle on Body Composition. SDÜ Sağlık Bilimleri Dergisi. 2016;7(2):23-27.

12. Çukurovalı Soykurt S. Determination of nutritional habits in women between the ages of 20-45 in all three stages of menstrual cycle (before menstrual period, menstrual period and post menstrual period). Başkent University, Institute of Health Sciences, Department of Nutrition and Dietetics, Master's Thesis. Ankara, Turkey. 2016.
13. Işgın K, Büyüktuncer Demirel Z. Nutritional approach in premenstrual syndrome. Turk Hij Den Biyol Derg. 2017;74(3):249-260.

14. Cheikh Ismail LI, Al-Hourani H, Lightowler HJ, Aldhaheri AS, Henry CJ. Energy and nutrient intakes during different phases of the menstrual cycle in females in the United Arab Emirates. An Nutr Metab. 2009;54(2):124-132.

15. Chung SC, Bond EF, Jarrett ME. Food intake changes across the menstrual cycle in Taiwanese women. Biol Res Nurs. 2010;12(1):37-46. doi: $10.1177 / 1099800410364554$

16. Hoyer J, Burmann I, Kieseler ML, et al. Menstrual cycle phase modulates emotional conflict processing in women with and without premenstrual syndrome (PMS)-a pilot study. PLoS One. 2013;24(8):59780. doi: 10.1371/ journal.pone.0059780

17. Costa YR, Fagundes RLM, Cardoso BR. Menstrual cycle and food consumption. Rev Bras Nutr Clin. 2007;22:203-209.

18. Sezer K, Zeyneloglu S, Güler N. Premenstrual syndrome incidence and affecting factors in university students. Gümüşhane University Journal of Health Sciences. 2012;1(4): 284-297.

19. Bronzi de Souza L, Anusca Martins K, Morais Cordeiro M, de Souza Rodriguez Y, Murino Rafacho BP, Bomfim RA. Do Food Intake and Food Cravings Change during the Menstrual Cycle of Young Women? Rev Bras Ginecol Obstet. 2018;40:686-692. doi: 10.1055/s-00381675831 
Table 1. Demographical information of individuals.

\begin{tabular}{|c|c|c|c|}
\hline \multicolumn{2}{|c|}{ Parameters } & $\mathbf{n}$ & $\%$ \\
\hline \multirow{3}{*}{ Education } & High school & 58 & 72.5 \\
\hline & Associate & 9 & 11.3 \\
\hline & Undergraduate & 13 & 16.3 \\
\hline \multirow{2}{*}{ Marital status } & Single & 74 & 92.5 \\
\hline & Married & 6 & 7.5 \\
\hline \multirow{2}{*}{ Accomodation } & Dormitory & 44 & 55.0 \\
\hline & Home & 36 & 45.0 \\
\hline \multicolumn{2}{|l|}{ Total } & 80 & 100 \\
\hline
\end{tabular}


Table 2. Anthropometric Measurements of Individuals During and After Menstruation.

\begin{tabular}{|l|c|c|c|}
\hline Measurements & $\begin{array}{c}\text { During menstruation } \\
\text { Mean } \pm \text { SD }\end{array}$ & $\begin{array}{c}\text { After menstruation } \\
\text { Mean } \pm \text { SD }\end{array}$ & p \\
\hline Body weight (kg) & $58.83 \pm 8.19$ & $58.51 \pm 8.11$ & $0.028^{*}$ \\
BMI (kg/m $\mathbf{m}^{\mathbf{2}}$ & $21.61 \pm 3.07$ & $21.49 \pm 3.03$ & $0.038^{*}$ \\
Waist circumference (cm) & $71.78 \pm 7.27$ & $70.88 \pm 7.54$ & $0.031^{*}$ \\
Hip circumference (cm) & $94.56 \pm 7.69$ & $94.27 \pm 7.67$ & $0.028^{*}$ \\
Waist/Hip Ratio & $0.75 \pm 0.07$ & $0.75 \pm 0.06$ & 0.078 \\
Chest circumference (cm) & $86.57 \pm 6.47$ & $86.00 \pm 6.48$ & $0.023^{*}$ \\
\hline
\end{tabular}

$* \mathrm{p}<0.05$ 
Table 3. Evaluation of energy and nutrient intake of individuals during and after menstruation.

\begin{tabular}{|l|c|c|c|}
\hline \multicolumn{1}{|c|}{ Nutrients } & During Menstruation & After Menstruation & \\
& & & \\
& Mean \pm SD & Mean \pm SD & \\
Energy (kcal) & & & \\
Protein (g) & $1556.10 \pm 347.75$ & $1575.63 \pm 429.82$ & 0.903 \\
Fat (g) & $58.55 \pm 19.29$ & $62.17 \pm 19.01$ & 0.171 \\
Carbonhydrate (g) & $75.56 \pm 22.70$ & $73.69 \pm 26.22$ & 0.294 \\
Fiber (g) & $156.55 \pm 42.14$ & $160.57 \pm 54.70$ & 0.294 \\
Unsaturated fatty acids (g) & $17.49 \pm 7.10$ & $18.32 \pm 7.81$ & 0.164 \\
Cholesterol (mg) & $16.20 \pm 7.70$ & $17.84 \pm 9.50$ & 0.227 \\
Vitamin A (mcg) & $276.48 \pm 443.35$ & $253.86 \pm 159.14$ & 0.472 \\
Vitamin E (mg) & $933.82 \pm 651.70$ & $963.97 \pm 847.30$ & 0.710 \\
Vitamin D (mcg) & $15.06 \pm 6.89$ & $15.65 \pm 8.86$ & 0.769 \\
Vitamin C (mg) & $1.32 \pm 1.64$ & $1.44 \pm 2.38$ & 0.599 \\
Vitamin B2 (mg) & $69.37 \pm 56.94$ & $74.03 \pm 51.18$ & 0.454 \\
Niacin (mg) & $1.16 \pm 0.36$ & $1.12 \pm 0.34$ & 0.149 \\
Vitamin B12 (mcg) & $14.73 \pm 8.33$ & $13.96 \pm 6.54$ & 0.732 \\
Folic Acid (mcg) & $3.55 \pm 2.23$ & $4.01 \pm 2.35$ & 0.197 \\
Iron (mg) & $206.17 \pm 71.85$ & $225.78 \pm 87.65$ & 0.069 \\
Calcium (mg) & $9.36 \pm 2.98$ & $9.66 \pm 3.67$ & 0.488 \\
Sodium (mg) & $670.06 \pm 248.50$ & $638.81 \pm 256.49$ & 0.402 \\
Zinc (mg) & $3478.15 \pm 1756.26$ & $3492.76 \pm 1461.24$ & 0.870 \\
Magnessium (mg) & $8.50 \pm 2.68$ & $9.09 \pm 3.52$ & 0.343 \\
& $237.64 \pm 78.20$ & $271.50 \pm 317.96$ & 0.694 \\
\cline { 1 - 2 } & & & \\
\hline
\end{tabular}


Table 4. The effect of menstruation on the appetite of individuals.

\begin{tabular}{|l|l|c|}
\hline \multicolumn{1}{|c|}{ Effect } & Appetite in the Premenstrual Period & n \\
\hline \multicolumn{3}{|c|}{} \\
\hline Increase & 50 & 62.5 \\
\hline Decrease & 3 & 3.8 \\
\hline No change & 27 & 33.8 \\
\hline Desire to consume foods in the premenstruation period which is not usually consumed \\
\hline Yes & 38 & 47.5 \\
\hline No & 42 & 52.5 \\
\hline Total & $\mathbf{8 0}$ & $\mathbf{1 0 0}$ \\
\hline
\end{tabular}

